\title{
Profitability and Marketing Efficiency of Smoked Fish: An Empirical Evidence from Ondo State, Nigeria
}

\author{
Taiwo Adedeji Foluso Osundare Abiodun Ajiboye \\ Department of Agricultural Economics and Extension Services, Faculty of Agricultural Sciences, Ekiti State \\ University, Ado-Ekiti, Nigeria
}

\begin{abstract}
The level of efficiency and profitability of the market and marketing functions are very important for sustainable marketing of agricultural products like fish. To ensure continuous availability of fish for human consumption, nutrition, and wellbeing, the Nigerian economy requires effective and efficient marketing systems. Fish marketing serves as a medium for bridging the gap between producers and consumers of fish. The study considers 80 fish marketers from Ondo state using purposive sampling technique. The data collected for the study were analysed using budgetary technique and shepherd efficiency model. The study revealed that fish marketing is profitable with gross margin of \#38,101.36 and $15 \mathrm{k}$ as return on investment. The shepherd efficiency model revealed that fish marketing activities among fish marketers is highly efficient with efficiency value far higher (558.0\%) than $100 \%$ deducing that an increase in the cost of performing marketing service (that is added time, form and place utility) by 100 percent will give a more than proportionate increase of 458.0 percent in the level of satisfaction derived from a kilogram of fish sold in the market. It was recommended that government should focus on policy that encourages farmers and young graduates in the business as it is noted for profitability, efficiency and a source of livelihood.
\end{abstract}

Keywords: Profitability, Marketing, Efficiency, Fish

DOI: $10.7176 / \mathrm{JMCR} / 58-04$

Publication date:July $31^{\text {st }} 2019$

\subsection{Introduction}

Marketing is one of the vital aspects of agriculture since agriculture entails the production of goods and services, and production is said not be completed until the commodity produced reaches the final consumer (Oladejo, 2016). According to Iliyasu, Onu, Midau and Fintan, (2011) agricultural production and fish marketing must develop hand in hand because they are partners in a progressive system. Meanwhile, considering the nature of fish as a highly perishable product lack of organized marketing system would no doubt result in low profit and efficiency respectively.

Consequently, the contribution of fisheries to the Nigerian economy is significant when viewed from the supply of animal protein and macro nutrient requirement, income and employment generation, rural development and exchange earning potentials (Foluke, 2007).

However, from the various studies cited (Bukenya, Theodora, Twinamasiko and Molnar, 2012; Osarenren and Ojor, 2014; Abah, Zaknayiba and Simon, 2013; Nsikan, Okon, Umoh and Nyong, 2015) fish marketing is constrained by low prices, low fish supply, sales of immature fish, inadequate fund, high transportation cost, inadequate storage facilities and high levy and other taxes. The nature of the product on one hand and lack of organized marketing system on the other often resulted in low profit and efficiency respectively.

Meanwhile, to be more profitable, fish trade requires every activity that increases sales revenue and as well decreasing the costs of marketing. Thus, prioritizing the adopted marketing strategies to improve profit becomes necessary, since profitability is the primary goal of all business. So measuring current and past profitability and projecting future profitability is very important. Profitability of fish is the measure of fish profit against its power to earn profit (Monica, 2014). Meanwhile on the previous investigation on the profitability of smoked fish marketing, Osarenren and Ojor, (2014) indicated that smoked fish was a profitable venture. Therefore, identification and adoption of the right market appealing to the consumers as a technique for achieving profitability can be said to be one of such right steps, because it enables fish farmers not only to produce and sell but also to maintain the right marketing delight with their customers which ends in enhancing profit which is the goal of the marketer.

Accordingly, marketing efficiency is a measure of market performance and is defined as the movement of crops and livestock from the producers to consumers at the lowest cost consistent with the provision of the services desired by consumers (Oladejo, 2016).

Nwaru, Nwosu and Agummuo, (2011) stated that an efficient marketing system ensures that goods which are seasonal will be available all year round, with little variation in prices, which can be attributed to cost of marketing functions like storage, processing, transportation, etc. A resourceful marketing system makes both the producers and consumers better off (Adegeye and Dittoh, 1985). And to ensure continuous availability of fish for human consumption, nutrition, and wellbeing, the Nigerian economy requires effective and efficient marketing systems. 
As a result of the foregoing, efficient fish marketing is important when distance distribution is necessitated, top quality, maximum yield and highest possible profits are to be achieved in the market (Davies and Davies, 2009). The questions that readily come to mind are: what are the socio-economic characteristics of the smoked fish marketers? What are the costs and returns involved in smoked fish marketing? What is the marketing efficiency of smoked fish in the area of study? It is against this background that this study investigated smoked fish marketing in Ondo state. Specifically, the study described the socio-economic characteristics of smoked fish marketers; determined the profitability and marketing efficiency of smoked fish in Ondo state.

\subsection{Methodology}

\subsection{The study area, Sampling Technique and Data Collection}

This study was carried out in Ondo-State, located within the southwest Nigeria. The major occupation of the people is farming particularly fish farming as well as other agricultural related activities along with trading and craft specialization.

Multistage sampling method was used to select eighty (80) marketers, by purposively selecting Lagos state in the first stage follow by the purposive selection of Ibeju Lekki local government in the second statge, purposively selecting Orimedu and Otto community in the third stage and the fourth stage involve the selection of marketers using snowball sampling. A primary source of data was employed in the course of this study. This was done by the use of well-structured questionnaire. Also open discussion, interview as well as physical observation were used to complement the data for accuracy and reliability.

\subsection{Analytical techniques}

The data obtained from the respondents were subjected to descriptive and inferential statistical. Descriptive statistics were used to describe the socio-economic characteristics while inferential statistics such as budgetary technique was employed to ascertain the profitability of fish marketing and shepherd index was used to determine the marketing efficiency of fish marketing in the study area.

\subsection{Model Specification}

The budgetary technique encompasses the analyses of the gross margin which involves the cost and return analysis of fish marketing in the study area. The gross margin formula is explicitly stated below:

The budgetary technique involves the cost and return analysis of fish marketing in the study area. It is explicitly stated as:

$\mathrm{G} . \mathrm{M}=\sum\left(\mathbf{P}_{\mathrm{ij}} \mathbf{Q}_{\mathrm{ij}}-\mathbf{r}_{\mathrm{ij}} \mathbf{X}_{\mathrm{ij}}\right)$

$\mathbf{P}_{\mathrm{ij}}=$ Price of fish in $\mathrm{i}^{\text {th }}$ for $\mathrm{j}^{\text {th }}$ respondent.

$\mathbf{Q}_{\mathrm{ij}}=$ Quantity of fish in $\mathrm{i}^{\text {th }}$ for $\mathrm{j}^{\mathrm{th}}$ respondent.

$\mathbf{r}_{\mathbf{i j}}=$ Price of Variable Input in $\mathrm{i}^{\text {th }}$ for $\mathrm{j}^{\text {th }}$ respondent.

$\mathbf{X}_{\mathrm{ij}}=$ Quantity of Variable Input in $\mathrm{i}^{\text {th }}$ for $\mathrm{j}^{\text {th }}$ respondent.

The profitability and efficiency ratio was calculated as follows:

Profitability ratio is given as: $\frac{\pi}{\pi V C}$

Efficiency ratio is given as: $\frac{T R}{T V C}$

a. $\quad \frac{T R}{T V C}>0=$ It is operational efficiency

b. $\quad \frac{T R}{T V C}<0=$ It is operational inefficiency

c. $\quad \frac{\pi}{T V C}>0=$ It is profitable

d. $\quad \frac{\pi}{T V C}<0=$ It is not profitable

Thus, the values in the Profitability and Efficiency ratio were computed in the marketing of fish in the study area. Where:

$\Pi=$ Profit

$\mathrm{TR}=$ Total Revenue

$\mathrm{TVC}=$ Total Variable Cost 
The Shepherd efficiency model developed by Shepherd, (1965) was used by Massoud and Gowda, (2012) to analyze the marketing efficiency of fish marketing by estimating as follows:

Marketing cost: The total marketing cost was determined by the following formula:

$$
\mathrm{TC}=\mathrm{C}_{\mathrm{P}}+\sum \mathrm{Mci}
$$

Where:

$\mathrm{i}=1$

$\mathrm{TC}=$ Total Cost of Marketing

$\mathrm{C}_{\mathrm{p}}=$ Producer cost of marketing

$\mathrm{Mc}_{\mathrm{i}}=$ Marketing cost by the ith trader

Marketing margin: The absolute margins of both the processed and unprocessed fish retailers were determined as follows:

$\mathrm{AM}=\mathrm{Psa}-(\mathrm{Pba}+\mathrm{Mc})$

$\mathrm{AM}=$ Absolute Margin

Psa $=$ Selling price

$\mathrm{Pba}=$ Buying price

$\mathrm{Mc}=$ Marketing cost

Producer' share in the consumer price: The producer' share in the consumer price was calculated by the following indicator:

$$
P s=\frac{P p}{P r} \times 100
$$

Ps $=$ Producer' share in the consumer price

$\mathrm{Pp}=$ Producer' price

$\operatorname{Pr}=$ Retail price or final consumer price

Marketing efficiency with Shepherd Index proposed to evaluate the marketing efficiency of fish marketing activities. It is given by:

$$
M E=\frac{P r}{T C+A M}
$$

$\operatorname{Pr}=$ Retail price or final consumer price

$\mathrm{TC}=$ Total Cost of Marketing

$\mathrm{AM}=$ Absolute Margin

$$
M E=\frac{\text { Value added by Marketing }}{\text { Marketing cost or cost of markeying services }} \times 100
$$

$\operatorname{Pr}=$ Retail price or final consumer price

$\mathrm{TC}=$ Total Cost of Marketing

$\mathrm{AM}=$ Absolute Margin

\subsection{Results and Discussion}

\subsection{Socio-Economic Characteristics}

The socio-economic characteristics of the respondent are presented in Table 1. The result shows that majority $91.25 \%$ of the respondents fell within the age bracket of 21 and 50 . This age bracket would favour fish marketing activities because the respondents would have enough strength to carry out fish marketing activities. The result of this study is in line with the findings of Sain (2008) who reported that the majority of the fish marketers were in active middle age.

The result of the gender distribution of the respondents shows that both sexes are involved in the marketing of fish. However, females are more prominent in fish marketing with $65 \%$. This result corroborates the findings of Adeleke and Afolabi, (2012) that fresh fish market was dominated by females. The results of marital status in the Table 1 show that $63.75 \%$ of the respondent was married. This deduces that there will be access to family 
labour required for fish processing and marketing. The distribution of the respondents by educational status shows that majority of the fish marketers had acquired formal education. For instance $86 \%$ of the fish marketers had formal education. The high literacy level would positively influence the marketing activities as observed by Madugu and Edward (2011). However, the proportion of marketers with non-formal was 7.5\%. The household size distribution of the respondents in the study area reveals that, $70 \%$ of the fish marketers were having between 1-5 members of household sizes. Meanwhile, the mean household size of marketers was 3.00 while the minimum and maximum were 1.60 and 6.00 respectively. This is an indication that there is less availability of family labour and family dependent between the marketers in the study area. Though, Unongo, (2010) concluded that family size is associated with the availability of timely labour where larger families are likely to be more effective. However, this study complements a similar study on fishing, that the lower the number of family dependent on marketers the better the market performance because less time is spent on family issues and more on marketing (Madugu and Edward, 2011).

\begin{tabular}{|c|c|c|}
\hline AGE & FREQUENCY & PERCENTAGE \\
\hline $20-30$ & 22 & 27.5 \\
\hline $31-40$ & 34 & 42.5 \\
\hline $41-50$ & 16 & 20 \\
\hline $51-60$ & 7 & 8.75 \\
\hline$>60$ & 1 & 1.25 \\
\hline \multicolumn{3}{|l|}{ GENDER } \\
\hline Male & 28 & 35 \\
\hline Female & 52 & 65 \\
\hline \multicolumn{3}{|c|}{ MARITAL STATUS } \\
\hline Single & 22 & 11.6 \\
\hline Married & 51 & 86.7 \\
\hline Divorced & 6 & 0.0 \\
\hline Widow & 2 & 1.7 \\
\hline \multicolumn{3}{|c|}{ EDUCATIONAL STATUS (years) } \\
\hline Primary & 18 & 22.5 \\
\hline Secondary school & 43 & 53.75 \\
\hline Tertiary school & 8 & 10 \\
\hline Non Formal & 6 & 7.5 \\
\hline No Formal & 5 & 6.25 \\
\hline \multicolumn{3}{|l|}{ HOUSEHOLD } \\
\hline $1-5$ & 56 & 70 \\
\hline $6-10$ & 12 & 15 \\
\hline$>10$ & 12 & 15 \\
\hline
\end{tabular}

Source: Field Survey 2011

\subsection{Profitability Analysis}

The measure of the cost and return analysis of the marketers in the study area was carried out using the budgetary technique. The result in Table 2 showed that the cost of purchase gulped up to $94.36 \%$ used by the fish marketers. The table revealed that a marketer earned an average revenue of $292,806.25$ but incurred a total variable cost of $\$ 254,704.88$ over the same period. This indicates that an average marketer earned $\$ 38,101.36$ as gross margin per year suggesting that fish marketing is a profitable venture in the study area. It can also be deduced that though the total variable cost was high it is also observed that it's gross margin is also higher in the like comparison, suggesting too that sale of fish is profitable. The result of the profitability ratio or the return on investment was 0.15 indicating that for every $\$ 1.00$ spent on fish marketing $15 \mathrm{kobo}$ is gained by the fish marketers in the study area. 


$\begin{array}{llc}\begin{array}{l}\text { Table 2: Computation of cost and return analysis of the marketers } \\ \text { Gross Margin Variables }\end{array} & \begin{array}{l}\text { Smoked Fish } \\ \text { Total Revenue }\end{array} & 23,424,500 \\ \text { Average Revenue } & \begin{array}{c}292,806.25 \\ \text { Variable Input }\end{array} & \text { Total variable Cost } \\ \text { Cost of purchase } & 19,228,341 & 94.36 \% \\ \text { Transportation } & 670,900 & 3.29 \% \\ \text { Labour } & 40,000 & 0.19 \% \\ \text { Bowl } & 120,700 & 0.59 \% \\ \text { Bracket } & 20,400 & 0.10 \% \\ \text { Wire gauze } & 78,250 & 0.38 \% \\ \text { Knife } & 22,300 & 0.10 \% \\ \text { Salting } & 16,350 & 0.08 \% \\ \text { Association fee } & 3,100 & 0.01 \% \\ \text { Storage } & 5,050 & 0.02 \% \\ \text { Rent (Space and others) } & 150,500 & 0.70 \% \\ \text { Security } & 20,500 & 0.10 \% \\ \text { Utility } & 0 & 0.00 \% \\ \text { Total TVC } & \mathbf{2 0 , 3 7 6 , 3 9 1} & \\ \text { Average TVC } & \mathbf{2 5 4 , 7 0 4 . 8 8} & \\ \text { Gross Margin (TR-TVC) } & \mathbf{3 , 0 4 8 , 1 0 9} & \\ \text { Average GM } & \mathbf{3 8 , 1 0 1 . 3 6} & \\ \text { Profitability ratio } & 0.15 & \\ \text { Source: Analysis of Field Survey } 2017 & & \\ & & \end{array}$

3.3 Marketing Efficiency of Coastline Fish Marketing in Southwest Nigeria

Marketing efficiency is the proportion between net marketing margin and marketing costs expressed as a percentage. A ratio of $100 \%$ (or 1.0) shows efficient trading/marketing activities. It essentially shows a break-even point since the value addition (i.e. marketing cost) is equal to the net margin obtained as a result of the value addition. Marketing efficiency value below $100 \%$ is suggesting inefficiency; more is spent on value addition compared to the margin received after value addition.

Results in Table 3 show that, fish marketing activities among fish marketers were highly efficient since the efficiency value was far higher than $100 \%(558.0 \%)$ deducing that an increase in the cost of performing marketing service (that is added time, form and place utility) by 100 percent will give a more than proportionate increase of 458.0 percent in the level of satisfaction derived from a kilogram of fish sold in the market. 


\begin{tabular}{|c|c|}
\hline Efficiency Variables & Values \\
\hline \multicolumn{2}{|l|}{ Total Cost of Marketing } \\
\hline Cost of Produce & $19,228,341$ \\
\hline Transportation & 670,900 \\
\hline Labour & 40,000 \\
\hline Bowl & 120,700 \\
\hline Bracket & 20,400 \\
\hline Wire gauze & 78,250 \\
\hline Knife & 22,300 \\
\hline Salting & 16,350 \\
\hline Association fee & 3,100 \\
\hline Storage & 5,050 \\
\hline Rent & 150,500 \\
\hline Security & 20,500 \\
\hline Utility & 0 \\
\hline Marketing cost by ith trader & $1,148,050$ \\
\hline Total Cost of Marketing & $20,140,691$ \\
\hline \multicolumn{2}{|l|}{ Absolute margin } \\
\hline Selling Price (Ps) & $23,424,500$ \\
\hline Total cost of marketing (Mc) & $20,140,691$ \\
\hline \multirow[t]{2}{*}{ Buying Price $(\mathrm{Pb})$} & $19,228,341$ \\
\hline & $-15,944,532$ \\
\hline \multicolumn{2}{|l|}{ Producer Share } \\
\hline Price of buying fish & $19,228,341$ \\
\hline Price of selling fish & $23,424,500$ \\
\hline Producer share & 0.82 \\
\hline Percentage of Producer share & $82 \%$ \\
\hline \multicolumn{2}{|l|}{ Marketing Efficiency } \\
\hline ME & 5.58 \\
\hline МE\% & $558.0 \%$ \\
\hline
\end{tabular}

Source: Analysis of Field Survey 2017

\section{Conclusion}

Based on the findings of this study, it could be concluded that, fish marketing is a profitable and efficient venture. Therefore, farmers and young graduate should be encouraged to venture into the business which would help reduce the menace of unemployment among young educated Nigerians.

\section{References}

Abah, D, D.B. Zaknayiba and Simon, E. (2013). Economic Analysis of Fish Marketing in Lafia Local Government Area of Nasarawa State, Nigeria: Production Agricultural Technology; 9 (2):53-62.

Adegeye, A. J. and Dittoh, J. S. (1985). Essentials of agricultural economics. Ibadan: Impact Publishers pp. 113 116.

Adeleke, M. L., Afolabi, J.A., (2012). Appraisal of Fresh Fish Marketing in Ondo State, Nigeria: IIFET Tanzanian Proceedings

Bukenya J. O., Theodora Hyuha, Julius Twinamasiko and Joseph Molnar (2012). "Economics of Fish Marketing in Central Uganda: A Preliminary Analysis". Selected Paper prepared for presentation at the Southern Agricultural Economics Association Annua lMeeting Birmingham, AL, February 4-7

Davies, R.M. and O.A. Davies, (2009). Traditional and improved fish processing technologies in Bayelsa State, Nigeria. Eur. J. Sci. Res., 26: 539-548.

Foluke O., (2007). "How fisheries contribute to food security in Nigeria "the national president of Fisheries Society of Nigeria, FISON

www.panoramaacuicola.com/noticias/2007/02/19/_how_fisheries_contribute_to_food_security_in_nigeria .html Iliyasu, A.H., J.I. Onu, A. Midau and J.S. Fintan, (2011). Economics of smoked and dried fish marketing in Yola North and South local Government areas of Adamawa State, Nigeria. J. Agric. Soc. Sci., 7: 13-16

Monica, T., (2014). Profitability Analysis (A comparative study of SAIL \& TATA Steel). IOSR Journal of Economics and Finance Vol. 3(2) pp. 19-22

Nsikan E. B., Okon E. U., Umoh I.U. and Nyong E. E., (2015). Analysis of the Determinants of Fresh Fish Marketing and Profitability among Captured Fish Traders in South South Nigeria: The Case of Akwa Ibom 
State: British Journal of Economics, Management and Trade 5(1): 35-45, 2015, Article no.2015.003 ISSN: 2278-098X

Nwaru, J. C., A. C. Nwosu and V. C. Agummuo (2011). Socio-economic determinants of profit in wholesale and retail banana marketing in Umuahia agricultural zone of Abia State, Nigeria. Journal of sustainable development in Africa. 13(1) 200-210.

Oladejo, J. A., (2016). Profitability and Marketing Efficiency Analysis of Women Cassava Processors in Oyo State, Nigeria. Global Advanced Research Journal of Agricultural Science Vol. 6(3) pp. 078-083

Osarenren C. O. and Adams O. Ojor, (2014). Marketing analysis of smoke-dried fish in Etsako East Local Government Area of Edo State, Nigeria. Net Journal of Agricultural Science, Vol. 2(3), pp.104-106, August 2014 ISSN: 2315-9766, Short Communication

Unongo, T. (2010): Economic Analysis of Artisanal Fishing Enterprises in Guma Local Government Area of Benue State, Nigeria. A thesis 